Antarctic Science 26(6), 758-773 (2014) C Antarctic Science Ltd 2014. This is an Open Access article, distributed under the terms of the Creative Commons Attribution licence (http://creativecommons.org/licenses/by/3.0/), which permits unrestricted re-use,

\title{
Antarctic subglacial hydrology: current knowledge and future challenges
}

\author{
DAVID W. ASHMORE ${ }^{1,3}$ and ROBERT G. BINGHAM ${ }^{2 *}$ \\ ${ }^{1}$ School of Geosciences, University of Aberdeen, Elphinstone Road, Aberdeen AB24 3UF, UK \\ ${ }^{2}$ School of GeoSciences, University of Edinburgh, Drummond Street, Edinburgh EH8 9XP, UK \\ ${ }^{3}$ now at: Centre for Glaciology, Institute of Geography and Earth Sciences, Aberystwyth University, Aberystwyth SY23 3DB, UK \\ *corresponding author: r.bingham@ed.ac.uk
}

\begin{abstract}
Flood-carved landforms across the deglaciated terrain of Victoria Land, East Antarctica, provide convincing geomorphological evidence for the existence of subglacial drainage networks beneath the Antarctic ice sheet, and motivate research into the inaccessible environment beneath the contemporary ice sheet. Through this research, our understanding of Antarctic subglacial hydrology is steadily building, and this paper presents an overview of the current state of knowledge. The conceptualization of subglacial hydrological behaviour was developed at temperate and Arctic glaciers, and is thus less mature in the Antarctic. Geophysical and remote sensing observations have demonstrated that many subglacial lakes form part of a highly dynamic network of subglacial drainage beneath the Antarctic ice sheet. Recent research into subglacial water flows, other than those directly concerned with lakes, has discovered potentially significant impacts on ice stream dynamics, ice sheet mass balance, and supplies of water to the ocean potentially affecting circulation and nutrient productivity. Despite considerable advances in understanding there remain a number of grand challenges that must be overcome in order to improve our knowledge of these subglacial hydrological processes.
\end{abstract}

Received 14 October 2013, accepted 8 June 2014

Key words: Antarctic ice sheet, geophysics, glaciology, ice penetrating radar, radio-echo sounding, subglacial lakes

\section{Introduction}

Situated on the current onshore margin of Victoria Land, East Antarctica $\left(c .161^{\circ} \mathrm{E}, 78^{\circ} \mathrm{S}\right)$, is a remarkable deglaciated landscape of channels up to $30 \mathrm{~km}$ long, potholes and plunge pools tens of metres deep and up to $70 \mathrm{~m}$ across, and areas of stripped and corrugated bedrock ranging in size from $100 \mathrm{~m}^{2}$ to $3 \mathrm{~km}^{2}$ (Fig. 1) that provides convincing evidence for the existence of significant subglacial water flows beneath the Antarctic ice sheet (Sugden et al. 1991, 2006, Sugden \& Denton 2004, Denton \& Sugden 2005, Lewis et al. 2006, Marchant et al. 2011). The size of the constituent landforms is comparable with the famous 'Channelled Scablands' landscape of the north-western USA, whose formation has been attributed to rapid flood events resulting from periodic drainage of ice-dammed glacial Lake Missoula during decay of the Pleistocene Laurentide Ice Sheet (Baker \& Bunker 1985). However, the routing of the channels in Victoria Land does not appear to be controlled by simple topographical gradients; rather it is clearly subglacial in origin, as modelled from classical Shreve theory (Shreve 1972, Marchant et al. 2011; see Fig. 2 for conceptual diagram). The downstream edges of channel networks are characterized by mega-ripples comprised of cobble-sized boulders, probably formed by the subglacial floodwaters. Dating of these deposits across the region indicates that they are at least 14 m.y.a. (Sugden \& Denton 2004, Margerison et al. 2005); hence, this channelized landscape was carved into the subglacial surface at a time when the East Antarctic Ice Sheet extended well beyond current limits. This labyrinthine landscape of subglacially carved channels stands as a clear monument to the intensity of subglacial water flows beneath the Antarctic ice sheet.

Therefore, it is perhaps surprising that, until the last decade, water flows beneath the Antarctic ice sheet have received little attention in the scientific literature. However, over the last decade several developments have transformed our understanding of subglacial water flows beneath the Antarctic ice sheet. These include: i) a growing realization of the significance of subglacial water flows to continental-scale ice dynamics (e.g. Siegert \& Bamber 2000, Pattyn et al. 2004, Fricker \& Scambos 2009), oceanic circulation (e.g. Evatt et al. 2006, Payne et al. 2007) and nutrient productivity (e.g. Statham et al. 2008, Skidmore 2011), ii) the development of remote sensing techniques that facilitate recovery or inference of subglacial conditions beneath the contemporary ice sheet (e.g. Robin et al. 1977, Blankenship et al. 1986, Smith 1997a), iii) enhanced imaging of subglacial hydraulic networks across continental shelf regions 


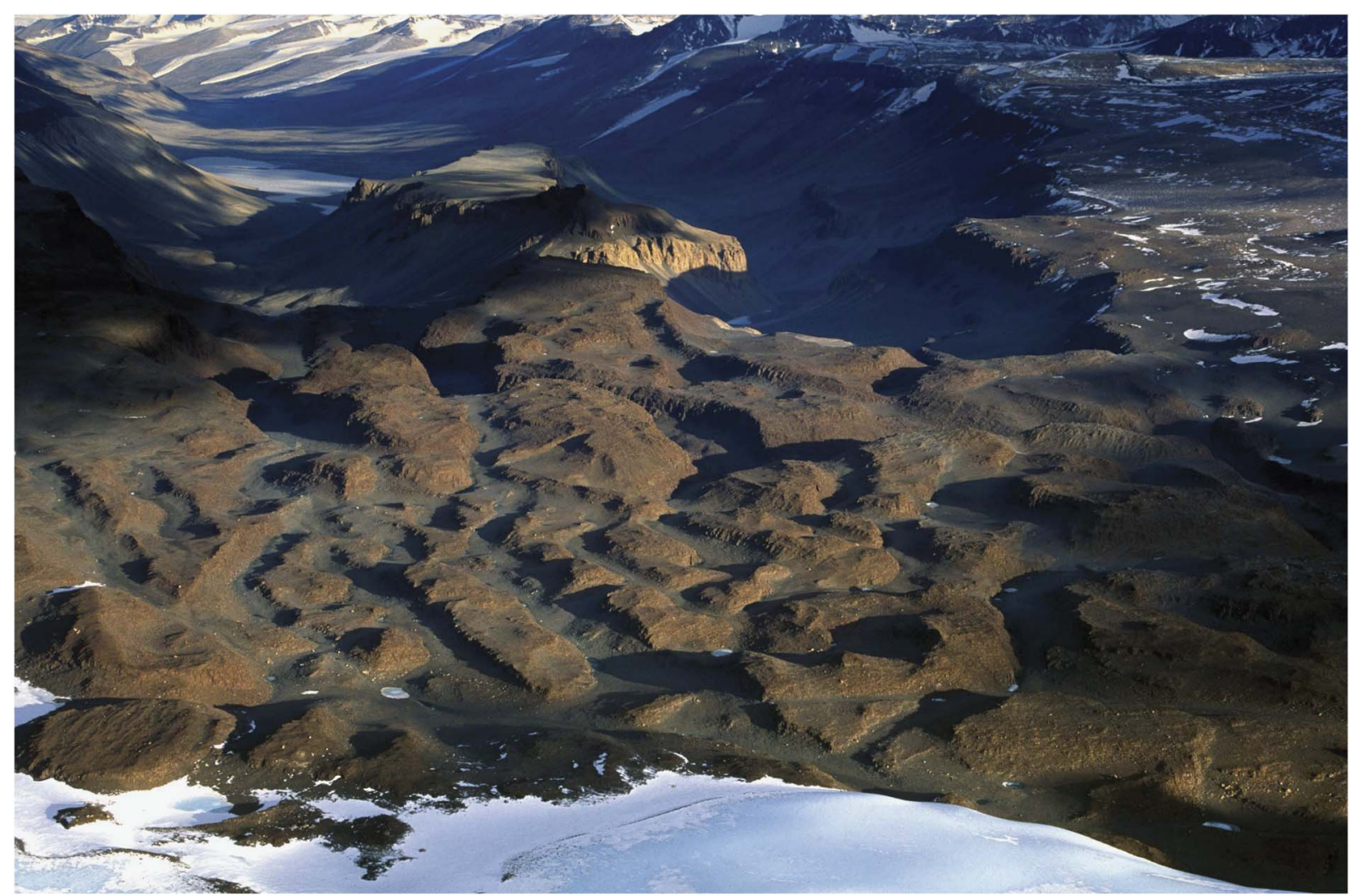

Fig. 1. The 'Labyrinth' subglacially-formed, and now deglaciated, channel system in western Wright Valley, Dry Valleys region, East Antarctica. Aerial view to the east. Channels are cut into dolerite. Individual channels are up to $100 \mathrm{~m}$ deep. The North Fork of Wright Valley is in the upper left background. Some potholes on the interfluves are littered with dolerite blocks, some of which are imbricated (photograph courtesy David Sugden; caption modified from Denton \& Sugden 2005).

previously covered by the expanded ice sheet (e.g. Nitsche et al. 2013), and iv) the constant refinement of glaciohydrological theories from other field sites, notably in Greenland (e.g. Zwally et al. 2002, Tedstone et al. 2013).

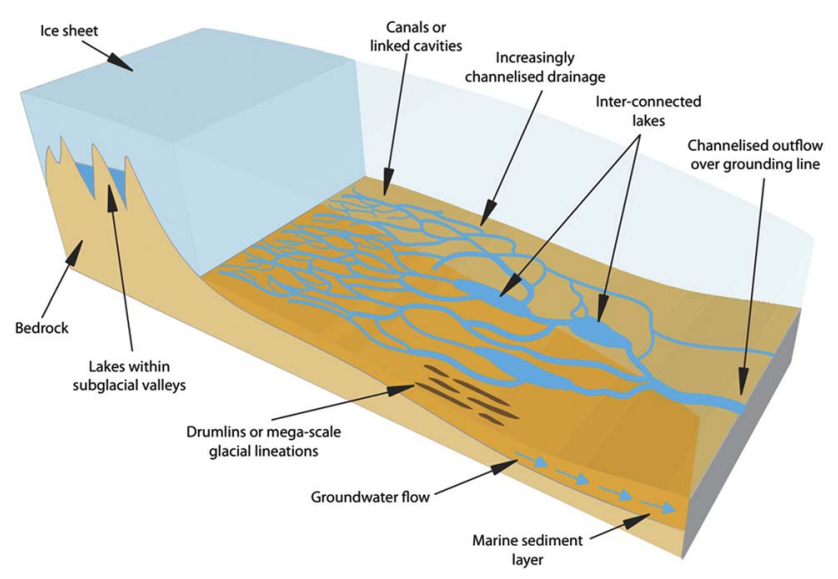

Fig. 2. Conceptual diagram of the typical situation of subglacial lakes and configuration of water flows beneath the Antarctic ice sheet.
The aim of this paper is to provide a brief overview of the current state of knowledge of subglacial hydrology across Antarctica, beginning by placing into context how knowledge of subglacial hydrology has grown from earlier studies mostly of alpine glaciers but more recently of those in the Arctic. This is followed by a discussion of where most hydrological attention in Antarctica has been focused until recently, namely the identification and exploration of subglacial lakes, before moving on to discuss examples of our burgeoning understanding of dynamic flows of water beneath the ice sheet. While many recent advances in understanding have been made, there remains much to be understood about the ways in which water is generated, stored, flows beneath and leaves the Antarctic ice sheet, and we therefore attempt to identify some of the grand challenges for improving our understanding of Antarctic subglacial hydrology. Figure 3 is provided as a reference guide for the Antarctic features and locations discussed.

\section{Context}

Scientists have been studying glacier hydrology for well over 40 years (for detailed reviews see Hubbard \& 


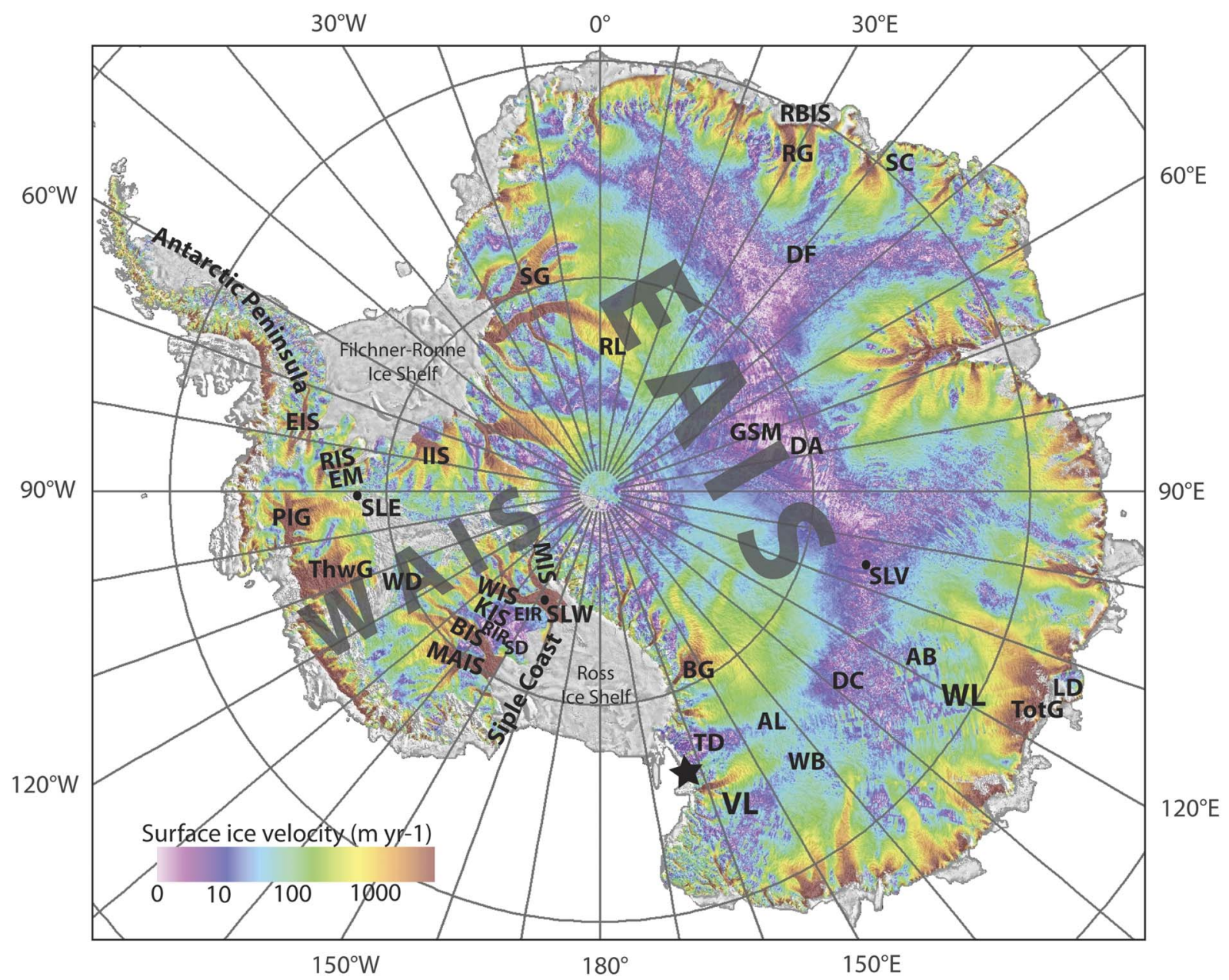

Fig. 3. Antarctic locations referred to in the text, using the ice-surface velocity map of Rignot et al. (2011), superimposed over the MODIS Mosaic of Antarctica as a basemap. The locations of subglacial lakes are denoted by circles, and the subglacial-flood landforms shown in Fig. 1 are located by the black star. An inventory of all known subglacial lake locations in Antarctica is provided by Wright $\&$ Siegert (2012). AB = Aurora Basin, AL = Adventure Lakes, BG = Byrd Glacier, BIS = Bindschadler Ice Stream, $\mathrm{DA}=$ Dome A, DC = Dome C, DF = Dome F, EAIS = East Antarctic Ice Sheet, EIR = Engelhardt Ice Ridge, EIS = Evans Ice Stream, GSM = Gamburtsev Subglacial Mountains, IIS = Institute Ice Stream, KIS = Kamb Ice Stream, LD = Law Dome, MAIS = MacAyeal Ice Stream, MIS = Mercer Ice Stream, PIG = Pine Island Glacier, RBIS = Roi Baudouin Ice Shelf, RG = Ragnhild Glaciers, RIR = Raymond Ice Ridge, RIS = Rutford Ice Stream, RL = Recovery Lakes, SC = Soya Coast, $\mathrm{SD}=$ Siple Dome, $\mathrm{SG}=$ Slessor Glacier, SLE = Subglacial Lake Ellsworth, SLV = Subglacial Lake Vostok, SLW = Subglacial Lake Whillans, TD = Taylor Dome, ThwG = Thwaites Glacier, TotG = Totten Glacier, VL = Victoria Land, WAIS = West Antarctic Ice Sheet, WB = Wilkes Basin, WD = WAIS divide, WIS = Whillans Ice Stream, WL $=$ Wilkes Land.

Nienow 1997, Fountain \& Walder 1998, Cuffey \& Paterson 2010). Important concepts from these studies include: i) glacial meltwater can be generated supraglacially, englacially and subglacially from various sources, ii) meltwater follows different flowpaths through glaciers (Cuffey \& Paterson 2010), iii) flowpaths can evolve in form with consequent impacts on the efficiency of water routing (Shreve 1972, Nienow et al. 1998), and iv) the form and efficiency of the subglacial drainage system exerts a significant impact on the motion of the overlying ice flow (Iken \& Bindschadler 1986, Mair et al. 2002). These concepts all hold for temperate glaciers, through which water flow is unrestricted by thermal considerations. For many years, the study of water flow through polythermal glaciers remained relatively unpursued, due in part to the conventional assumption that large proportions of cold ice would act to limit significant water flows, thereby preventing significant subglacial drainage system evolution and any hydraulic instabilities that might exert significant impacts on ice motion. Work by Müller \& Iken (1973) on White Glacier, Arctic Canada, contradicted this assumption at an early stage, but it was not until a series of field studies on Arctic polythermal glaciers during the 1980s and 1990s that it 


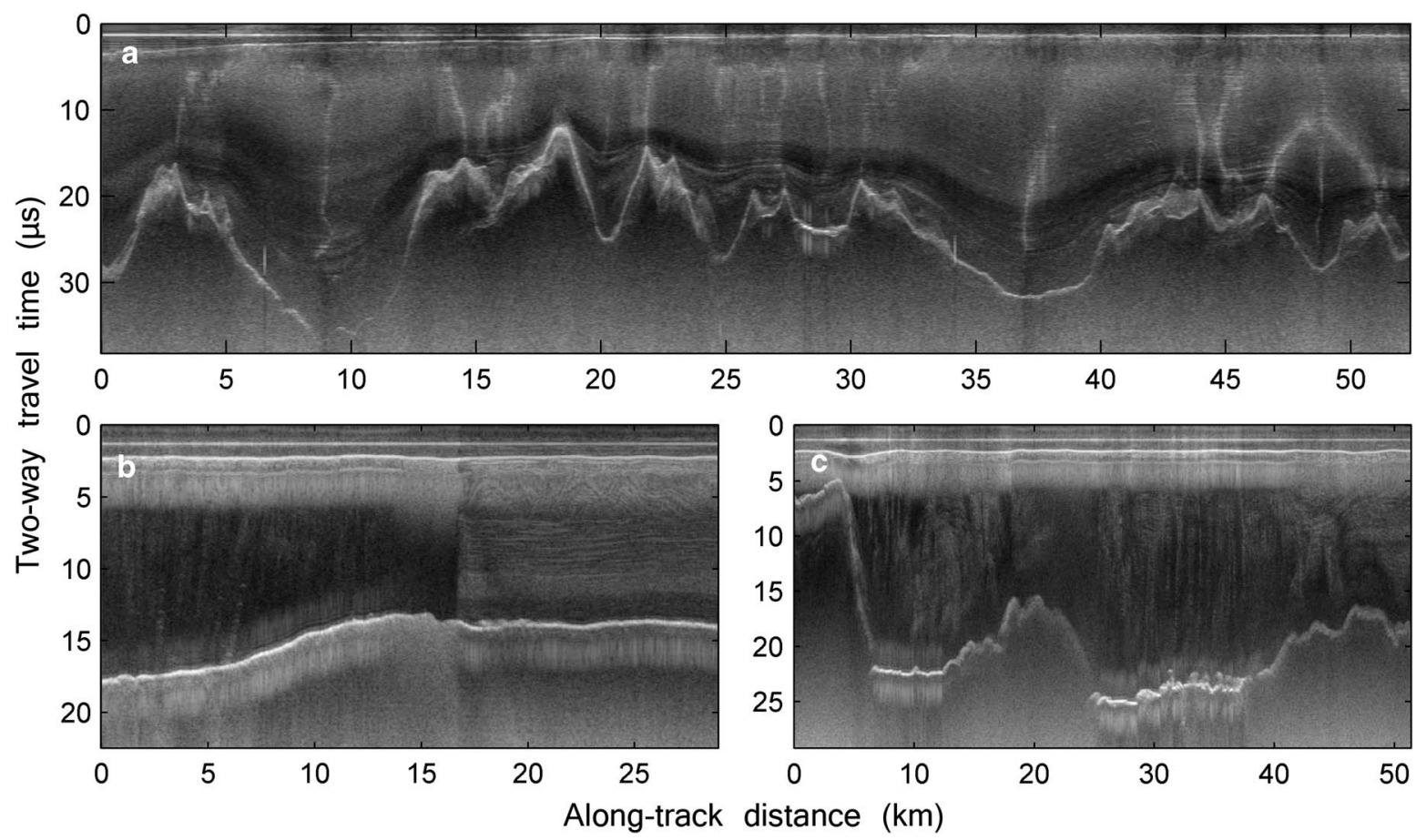

Fig. 4. Radargrams of the West Antarctic subglacial hydrological environment. a. Subglacial highlands near the West Antarctic divide showing steep, complex topography and well-preserved internal layers; note the bright reflection $27 \mathrm{~km}$ along-track indicating pooled water. b. The margin of Evans Ice Stream demonstrating the contrast between the ice stream, characterized by a bright reflection and absent-layering (left) and dimmer reflection and well-preserved layering in the slow-moving area (right). c. Flat and bright reflectors at the base of subglacial valleys; note their non-specular nature indicating the presence of saturated sediment, rather than a 'definite lake' (cf. Carter et al. 2007).

became more readily accepted that drainage systems at polythermal glaciers do evolve, and that this can have readily observable impacts on patterns of ice flow (e.g. Hock \& Hooke 1993, Bingham et al. 2008). Translation and upscaling of these concepts to various locations on the Greenland ice sheet has brought the issue to global attention (Zwally et al. 2002, Van de Wal et al. 2008, Bartholomew et al. 2010, Sundal et al. 2011, Tedstone et al. 2013), and shown the significance of hydrological processes for ice dynamics at the ice-sheet-scale (e.g. Price et al. 2008, Shannon et al. 2013).

Antarctica continues to present a distinct glaciohydrological context. Under current climatic conditions the $0^{\circ} \mathrm{C}$ isotherm is rarely reached anywhere across West or East Antarctica, hence surface melt is limited to non-existent, and supraglacially-forced processes, which are considered to be responsible for inducing ice dynamic feedbacks in Arctic polythermal glaciers, cannot occur. A caveat to this is presented by the warmer, northward-trending Antarctic Peninsula region, in which it is conceivable that supraglacially-forced englacial connections could be established, thereby inducing polythermal-glacier drainage-system evolution and dynamic effects similar to those observed in the Arctic. Although this process has not been observed directly on Antarctic Peninsula polythermal glaciers, indirect evidence for its feasibility is provided by the demonstrable establishment of supraglacial-subglacial water connections on fringing ice shelves, which occasionally significantly impacts ice shelf stability and the glaciers formerly buttressed by them (Glasser \& Scambos 2008). However, for the Antarctic Peninsula glaciers overall, even though supraglacial-subglacial connections might occur, it is probable that their significance in any form of ice dynamic response mediation (cf. Hulbe et al. 2008) is far outweighed by their collective and dramatic response to oceanic forcing along the coastline (Pritchard et al. 2009).

This paper will not discuss the Antarctic Peninsula region further and will focus on the West and East Antarctic ice sheets, which comprise the vast majority of ice cover across the continent, and for which the subglacial hydrology remains only tentatively understood. A conceptual diagram for the following discussion is provided in Fig. 2.

\section{Subglacial lakes}

Beneath the contemporary continental ice sheets of Antarctica the identification and interrogation of 
subglacial hydrological phenomena is dependent upon multiple remote sensing techniques. In the late 1960s, scientists using airborne radar to survey ice thickness across the continent reported very clear, unusually strong and flat basal reflectors at many localities, which they interpreted as distinct bodies of collected subglacial water, or 'subglacial lakes' (Robin et al. 1977). Subglacial lakes are found wherever sufficient water is generated at the base of the ice sheet and gathers into depressions in hydraulic potential (Dowdeswell \& Siegert 2003) and where inflow at least equals, if not exceeds, outflow. For several decades, the study of Antarctic subglacial hydrology has been synonymous with the identification of subglacial lakes, and elucidation of their formation and behaviour. This is because they are clearly identified in radio echo sounding (RES) data (e.g. Robin et al. 1977, and Fig. 4) and their significance is manifold, for example in their capacity to support life or impact on overlying ice dynamics (e.g. Siegert et al. 2011). Successive inventories of Antarctic subglacial lakes have been published; initially using only the clearest lake-like returns visible in RES data but progressively incorporating ancillary forms of satellite observations (e.g. Fricker et al. 2007, Wright \& Siegert 2012) and multiple-attribute processing of new digital radar data (e.g. Carter et al. 2007). The most recent inventory provides the locations of 379 subglacial lakes (Wright \& Siegert 2012). The largest lakes are clearly expressed by depressions in the ice surface (e.g. Ridley et al. 1993), which has been mapped from satellite observations across the continent (Bamber et al. 2009). It is therefore probable that all of the most substantial subglacial lakes across Antarctica have now been identified. However, even the basic dimensions of most of the lakes are not known, i.e. depth and volume, and there are undoubtedly many smaller lakes beneath the ice cover, which will continue to be discovered as RES surveys continue to explore the subglacial environment (Wright \& Siegert 2012). Recent work by Livingstone et al. (2013) offers potential in efforts to pinpoint the locations of smaller lakes where knowledge of the bed is good.

Before the last decade, most research on subglacial lakes explicitly or implicitly treated them as isolated, relatively stable, 'closed-system' phenomena. This led many to conceive of subglacial lakes as potential refugia, isolated and unique from elsewhere on Earth for millions of years (e.g. Priscu et al. 1999). This arresting notion motivated several high profile efforts to sample subglacial lake environments directly over recent years. Direct sampling was also driven by the potential of the lake bottom sediment profiles to record the overlying ice history (Bentley et al. 2011). Scientific drilling projects at the subglacial lake sites of Vostok and Ellsworth were particularly motivated by the search for subglacial life. Lake Vostok, East Antarctica, is the continent's largest known subglacial lake with an estimated volume of $5400 \mathrm{~km}^{3}$ (Studinger et al. 2004). It contains water that actively circulates and accretes onto the underside of the ice sheet at its southern end (Siegert et al. 2000, Bell et al. 2002), and preliminary samples of the accreted ice have provided evidence for the presence of microorganisms in the lake (Shtarkman et al. 2013). Lake Ellsworth fills an overdeepened former fjord flanking the Ellsworth Mountains in West Antarctica, which contains $1.37 \mathrm{~km}^{3}$ of water (Woodward et al. 2010). During 2012-13, another subglacial lake, Lake Whillans, West Antarctica, was the subject of scientific drilling investigations. Lake Whillans covers a $c .60 \mathrm{~km}^{2}$ region beneath Whillans Ice Stream and is a much shallower feature, probably only $c .2 \mathrm{~m}$ deep across much of its extent (Christianson et al. 2012, Horgan et al. 2012). Although Lake Whillans may harbour life and access to the subglacial sediments may provide information on the ice-flow history (Fricker et al. 2011), the initial discovery in 2007 by satellite altimetry, exposing it as a site of distinct cyclical ice-surface rise and fall (Fricker et al. 2007), pointed to strong dynamism in the subglacial hydraulic environment, motivating further investigation.

Over the last decade, a significant body of evidence has accumulated to demonstrate that many subglacial lakes form part of an interconnected network, draining up-gradient locations to down-gradient locations and ultimately to the ice sheet margin. This hypothesis was established by Dowdeswell \& Siegert (2003), but the first observational confirmation of its veracity was provided by Spikes et al. (2003) and Gray et al. (2005), who interpreted satellite signals of isolated ice surface elevation change in the Siple Coast region of West Antarctica as the expressions of episodic drainage/fill events in connected subglacial lakes. Subsequently, Wingham et al. (2006) used radar altimetry to record movement between pairs of subglacial lakes over tens of $\mathrm{km}$ in East Antarctica. Fricker et al. (2007) and Fricker \& Scambos (2009) utilized satellite laser altimetry to record pervasive, connected subglacial lake activity across lower Mercer and Whillans ice streams in West Antarctica. Smith et al. (2009) collated all satellite laser altimeter observations of vertical ice surface change across Antarctica between 2003 and 2008 that could conceivably reflect subglacial lake drainage/filling events to produce an inventory of 124 'active' subglacial lakes across the Antarctic ice sheet. These observations strongly suggest that the treatment of subglacial lakes as isolated, closed systems is inherently flawed, and that it is more appropriate to consider each lake as part of an open system. Recent RES surveys of some of the 'active' lake sites that do not show the classic lake-like reflectors support this view, suggesting that at those sites the lakes may periodically experience wholesale drainage or that they are very shallow. An alternative explanation is that 
the surface movement detected by altimetry is not a signal of lake drainage/filling but rather the surface expression of subglacial migration of packets of basal water or sediment flows facilitated by changes to subglacial hydrological routing (Wright \& Siegert 2012, Siegert et al. 2014). This interpretation implies that in some areas the storage of water and sediment is relatively temporary, and driven by internal hydrological (re)organization; consequently, caution should be applied when interpreting surface uplift/subsidence as the location of a fixed 'lake' that drains and recharges with some periodicity. Either explanation for the mismatch appeals to considerable dynamism in the subglacial hydrological system.

The impact of subglacial lakes on vertical ice motion, in some cases through several $\mathrm{km}$ of ice, highlights their potentially pervasive influence on ice dynamics. Siegert \& Bamber (2000), Pattyn et al. (2004), Bell et al. (2007) and Peters et al. (2007) have all noted that subglacial lakes towards the ice sheet interiors coincide with ice stream onset regions and may, therefore, play a critical role in defining the configuration of drainage across Antarctica. This is particularly true in areas of East Antarctica where thick inland ice causes large areas of the bed to be at pressure melting point, allowing liquid water to collect in hydraulic potential lows caused by low ice surface slopes and rough subglacial topography. Of further significance, Stearns et al. (2008) linked a 14-month acceleration of Byrd Glacier, East Antarctica, to the drainage of two subglacial lakes $c .200 \mathrm{~km}$ further upstream. To explain the acceleration (and subsequent deceleration) of this glacier, Stearns et al. (2008) drew directly on established relationships between subglacial hydrological configurations and ice dynamics of temperate glaciers developed by Kamb (1987). These papers have been especially important in underscoring that: i) subglacial water clearly has the capacity to travel long distances through drainage networks beneath the Antarctic ice sheet, and ii) it is the flow of subglacial water from one place to another, especially if there are sudden changes in volume, that may have the most profound influence on ice dynamics. The latter point is profoundly familiar to researchers with a background in temperate and Arctic polythermal glaciers and, more recently, the Greenland ice sheet, although in these cases the most variable and glaciodynamically significant water flows tend to be induced by surface melt penetrating to the bed, whereas in Antarctica alternative forcing mechanisms should be considered. Periodic subglacial lake drainage provides one such mechanism (Evatt et al. 2006, Pattyn 2011).

\section{Subglacial water away from lakes}

This section will focus on observations and theories of subglacial water generation and flow beneath the
Antarctic ice sheet, separate from the explicit study of subglacial lakes. A seminal programme of studies on the Siple Coast ice streams, initiated in the 1980s, provided some of the earliest observational groundwork for the existence of distributed water at the beds of ice streams and their tributaries. Using seismic techniques, Blankenship et al. (1986) presented the first evidence to show that the bed of an active ice stream, in this case Whillans Ice Stream, was composed of water-saturated sediments. Alley et al. (1989) demonstrated the crucial importance of this water in facilitating deformation of the underlying sediments and therefore fast flow in the overlying ice. Drilling to the bed of this ice stream, Engelhardt et al. (1990) confirmed that the bed was at pressure melting point and that the subglacial water was highly pressurized. Subsequent experiments demonstrated that the subglacial water pressures (hence, inferred water flows) were highly variable (Engelhardt \& Kamb 1997). Part of the variability could be attributed to tidal influences at sites sufficiently proximal to the grounding line; but there was also considerable unexplained variability in water pressure, which, they argued, acted cumulatively to support continued fast flow of overlying ice. Parallel studies by Smith (1997a, 1997b) and Vaughan et al. (2003) also derived seismic acoustic-impedance to argue for the existence of wet sediments beneath several additional West Antarctic ice streams, while King et al. (2004) presented seismic evidence that water may be routed through small channels, or 'canals', along the Rutford Ice Stream bed. All of these studies, and further analysis of RES bed reflectivity, have shown that most ice streams, and many ice stream tributaries, are underlain by ice at pressure melting point, contrasting with surrounding regions commonly underlain by cold-based ice. Therefore, the presence of water is crucial to ice dynamics in many areas and for determining the current configuration of ice flow across Antarctica. However, the mechanisms by which the water is generated, and the specific processes by which it flows and impacts upon overlying ice dynamics, remain poorly understood. For example, the presence of water at the bed alone is not exclusively responsible for the fast flow of ice, as verified by the existence of water beneath the currently stagnated Kamb Ice Stream (Catania et al. 2003). Moreover, the fast flow of the tributaries of Slessor Glacier, East Antarctica, appears to be initiated by ice deformation alone (Rippin et al. 2003), with subglacial water only becoming available farther downstream, presumably when frictional heat sources sufficiently elevate basal temperatures.

With supraglacial and englacial meltwater sources ruled out, sources of basal water beneath the Antarctic ice sheet must be derived predominantly from geothermal heating and pressure melting. Additional contributions may come from: i) frictional heating generated by ice 
Table I. Summary of radioglaciological studies in which bed-reflection power (bed reflectivity) has been acquired across parts of the Antarctic ice sheet organized chronologically by survey date. Traverses between locations are denoted by hyphenation. Only Antarctic-focused studies from the last 15 years specifically concerned with the basal reflectivity of grounded ice are listed. Bright reflections have been used to (semi-)qualitatively delineate subglacial lakes since the 1960s and such studies are not included here.

Location
Whillans Ice Stream \& Kamb Ice
Stream
Kamb Ice Stream \& Siple Dome
region
Dome C
Soya Coast-Dome F-EPICA
DMLWasa
Mercer Ice Stream-South Pole;
Wilkes Basin-Dome C; Lake
Vostok region
Engelhardt Ice Ridge-Whillans Ice
Stream; Siple Dome-Kamb Ice
Stream

Dome C
Siple Ice Stream-Siple Dome; Raymond Ice Ridge (Ridge CD)-Kamb Ice Stream-Engelhardt Ice Ridge (Ridge BC)

Slessor Glacier

\section{Whillans Ice Stream, Engelhardt Ice Ridge (Ridge BC) and Kamb Ice Stream}

Thwaites Glacier and margin

Thwaites Glacier

$$
\begin{aligned}
& \begin{array}{l}
\text { Radar system and survey date } \\
\text { (if reported) }
\end{array} \\
& 50 \mathrm{MHz} \text { airborne, SPRI Mark IV; } \\
& 1987-88 \\
& \\
& 4 \mathrm{MHz} \text { and } 3 \mathrm{MHz} \text { oversnow; } \\
& 1994-95,1996-97
\end{aligned}
$$

$60 \mathrm{MHz}$ 'GlacioRadar'; 1995, 1997, 2003

$179 \mathrm{MHz}, 180 \mathrm{MHz}, 60 \mathrm{MHz}$ oversnow; 1996-97, 2007-08

$60 \mathrm{MHz}$ airborne, UTIG HiCARS; 1997-98 (Mercer/S. Pole), 1999-2000 (Wilkes/Dome C), 2000-01 (Vostok)

2 MHz oversnow; Nov-Dec 1998

$60 \mathrm{MHz}$ airborne, UTIG/SOAR; 1999-2000

c. $2 \mathrm{MHz}$ and c. $5 \mathrm{MHz}$ oversnow; Nov-Dec 2000, January 2002

$150 \mathrm{MHz}$ airborne, BAS PASIN; 2001-02

$60 \mathrm{MHz}$ airborne, UTIG; 2001 (also re-analysing $50 \mathrm{MHz}$ airborne, SPRI Mark IV; 1987-88)

$60 \mathrm{MHz}$ airborne, UTIG HiCARS; AGASEA 2004-05

$60 \mathrm{MHz}$ airborne, UTIG HiCARS; AGASEA 2004-05

Major findings

Reference

\section{Wet bed beneath stagnant and active ice streams on the Siple Coast and a frozen bed beneath ridge}

Siple Ice Stream underlain by thin layer of water or thawed till, Siple Dome underlain by thin frozen till

\section{A wet bed is widespread in Concordia} Trench and patchy beneath highland areas

Novel technique to map wet/dry transition based on BRP-ice thickness relationship. Subglacial lowlands typically wet and highlands frozen

Subglacial lakes occupy a range of environments ('swamps', shallow pools) beyond classic 'definite' lakes

Low-BRP extends from ridge beneath 'chaotic' region at margin implying fast flow in marginal ice is not due to deformation of thick saturated till

Internal layers and ice chemistry used as input in attenuation model. Wet bed and melt mapped in subglacial basins, frozen bed in highlands

Wet-frozen bed transition mapped across shear margins. Intermediate reflectivity linked to regions with low hydrological connectivity

\section{Strong bed reflections beneath ice stream/tributaries associated with smooth (\& maybe wet) bed; while ridge areas have weaker bed reflections associated with rougher topography}

Classification of bed based on BRP and scattering determined using different aperature range-migration and phase analysis

Modest change in bed properties across shear margin implies migration is possible

Distributed channels upstream of bedrock ridge, lower ice stream dominated by channelized system
Bentley et al. (1998)

Gades et al. (2000)

Zirizotti et al. (2010, 2012)

Fujita et al. (2012)

Carter et al. (2007)

Raymond et al. (2006)

Carter et al. (2009a)

Catania et al. (2003)

Rippin et al. (2004)

Peters et al. (2005)

MacGregor et al. (2013)

Schroeder et al. (2013) 
Table I. Continued

\begin{tabular}{|c|c|c|c|}
\hline Location & $\begin{array}{l}\text { Radar system and survey date } \\
\text { (if reported) }\end{array}$ & Major findings & Reference \\
\hline Rutford Ice Stream & $\begin{array}{l}150 \mathrm{MHz} \text { airborne, BAS PASIN; } \\
2004-05\end{array}$ & $\begin{array}{l}\text { Comparison of BRP with seismically- } \\
\text { inferred areas of basal sliding and } \\
\text { deformation; water patches in sliding } \\
\text { regions and canals in deforming regions }\end{array}$ & Murray et al. (2008) \\
\hline Siple Dome-Kamb Ice Stream & $\begin{array}{l}3 \mathrm{MHz} \text { oversnow impulse; } 2004-05 \text {, } \\
\text { 2006-07 }\end{array}$ & $\begin{array}{l}\text { Wet bed is pervasive throughout KIS } \\
\text { trunk, KIS sticky spot is probably } \\
\text { largely frozen to bed }\end{array}$ & Jacobel et al. (2009) \\
\hline West Antarctic Ice Sheet divide & $\begin{array}{l}\text { 120-300 MHz ultra-wide-band } \\
\text { airborne; 2005-06 }\end{array}$ & $\begin{array}{l}\text { Patches of high and low BRP beneath } \\
\text { divide }\end{array}$ & Laird et al. (2010) \\
\hline $\begin{array}{l}\text { Kamb Ice Stream \& Engelhardt Ice } \\
\text { Ridge }\end{array}$ & $5 \mathrm{MHz}$ oversnow; 2005-06 & $\begin{array}{l}\text { Evidence for accreted seawater in basal } \\
\text { crevasses on parts of KIS }\end{array}$ & Matsuoka et al. (2009) \\
\hline $\begin{array}{l}\text { Kamb Ice Stream-Ross Ice Shelf; } \\
\text { Whillans Ice Plain-Ross Ice Shelf }\end{array}$ & $2 \mathrm{MHz}$ oversnow; 2006, 2007 & $\begin{array}{l}\text { Thin water layer extends well upstream of } \\
\text { grounding lines indicating gradual } \\
\text { transition to floating ice }\end{array}$ & MacGregor et al. (2011) \\
\hline Rutford Ice Stream & $\begin{array}{l}3 \mathrm{MHz} \text { oversnow monopulse; } \\
\text { 2007-08 }\end{array}$ & $\begin{array}{l}\text { Higher BRP at crests of MSGL in areas of } \\
\text { thin dilating till, and vice versa }\end{array}$ & King et al. (2009) \\
\hline Recovery Lakes & $3 \mathrm{MHz}$ oversnow; 2008-09 & $\begin{array}{l}\text { BRP evidence for less extensive Recovery } \\
\text { Lakes than inferred from satellite } \\
\text { imagery; interpreted as evidence for } \\
\text { drainage }\end{array}$ & Langley et al. (2011) \\
\hline Aurora Subglacial Basin & $\begin{array}{l}60 \mathrm{MHz} \text { airborne, UTIG HiCARS; } \\
\text { ICECAP, 2008-09, 2009-10 }\end{array}$ & $\begin{array}{l}\text { Lakes present in the deep interior route } \\
\text { water to margin, although very high } \\
\text { BRP indicative of 'definite' lakes is } \\
\text { relatively uncommon }\end{array}$ & Wright et al. (2012) \\
\hline Subglacial Lake Whillans & $\begin{array}{l}\text { c. } 5 \mathrm{MHz} \text { oversnow impulse; } \\
\text { Dec } 2010\end{array}$ & $\begin{array}{l}\text { Lake extent limited by basal topography } \\
\text { and no clear 'definite' lake reflection }\end{array}$ & Christianson et al. (2012) \\
\hline Institute Ice Stream & $\begin{array}{l}150 \mathrm{MHz} \text { airborne, BAS PASIN; } \\
2010-11\end{array}$ & $\begin{array}{l}\text { Incomplete correspondence between } \\
\text { 'active' lake inventoried by Smith et al. } \\
\text { (2009) and radar reflectivity over 'lake' }\end{array}$ & Siegert et al. (2014) \\
\hline
\end{tabular}

BRP = bed-returned power, DMLWasa = Dronning Maud Land Wasa expedition, EAIS = East Antarctic Ice Sheet, EPICA $=$ European Project for Ice Coring in Antarctica, KIS = Kamb Ice Stream, MSGL = mega-scale glacial lineations.

motion over the subglacial substrate, ii) occasional release of water through the regelation process (Weertman 1957), and iii) (at a local level) drainage from subglacial lakes or reservoirs upstream. However, the distribution of geothermal heating beneath Antarctica is notoriously poorly constrained due to a dearth of observations. 
In the last decade, two modelled distributions of geothermal heat flux across the Antarctic bed have been derived: the first extrapolated from a global seismic model of the Earth's crust and upper mantle (Shapiro \& Ritzwoller 2004) and the second derived from satellite magnetic measurements (Maule et al. 2005). Both have been used in ice sheet modelling to derive continent-wide maps of basal thermal conditions (Pattyn 2010, Van Liefferinge \& Pattyn 2013) but they differ in many details, rendering significant uncertainty to any interpretations of subglacial water distribution. At a broad level, both models show much greater geothermal heat flux across West Antarctica relative to East Antarctica, supporting (though not confirming) claims of active volcanism beneath the West Antarctic Ice Sheet (Blankenship et al. 1993). Brief periods of volcanic activity may be responsible for producing surplus meltwater sufficient to induce excess basal slip in some localities (Vogel \& Tulaczyk 2006, Corr \& Vaughan 2008), in effect aping the transient lake-drainage-triggered acceleration of Byrd Glacier reported by Stearns et al. (2008). The importance of active volcanism to the overall pattern of ice dynamics in Antarctica remains debated.

To expand upon observational records of the distribution and processes of water flow beneath the Antarctic ice sheet, several teams from the 1980s onwards examined the properties of bed returns in RES data for signals of water and its variations, i.e. other than identifying just the obvious lake-like reflectors. Shabtaie et al. (1987) argued that relative reflection amplitudes, after corrections for variations in ice thickness and taking into account possible variations in subglacial geology, varied inversely with freezing at the bed. Bentley et al. (1998) later applied a revised version of this scheme to suggest high bed reflection amplitudes beneath Kamb Ice Stream evinced liquid water at its base, while low relative reflection amplitudes beneath neighbouring Engelhardt Ice Ridge were indicative of frozen till. Gades (1998) drew on these studies, and from radar work on temperate glaciers, to develop a range of 'bed reflection powers' for subglacial materials from frozen permafrost to liquid water, then applied this classification to the subglacial interface sounded across Siple Dome (Gades et al. 2000). This study showed that while the dome was frozen to the bed, the ice streams flanking it were underlain by water-saturated material. Subsequent RES surveying and recovery of bed reflection power (as quantified by the amplitudes of the bed-return waves) across a number of the Siple Coast ice streams, calibrated with observations of water content in nearby boreholes, confirmed the contention that the ice streams (including the currently stagnant Kamb Ice Stream) are underlain by wet sediment, while in the intervening ridges the water is frozen to the bed (Catania et al. 2003, Peters et al. 2005).
In recent years, the use of RES to search for water beneath the Antarctic ice sheet has been adopted as a standard part of any survey, and has been applied far beyond the Siple Coast region, into other parts of West Antarctica and across East Antarctica. Table I provides a summary of surveys and significant findings (see also example RES data presented in Fig. 4). In acquiring and analysing more recent data and, in some cases, retrospectively analysing older surveys, research has advanced from the simple binary exercise of distinguishing between 'dry' and 'wet' beds, and significant developments have been made. Firstly, now that modern RES systems are fully digitized, bed returns can be acquired at much higher resolution and the collected data analysed with much greater efficiency. Though data are always degraded by beam spreading, limiting our ability to acquire data at the resolution of many hypothesized subglacial system structures, the recovery of hydrological variability at finer resolution is much improved. Technical advances in data acquisition, such as synthetic aperture processing radio echo sounding platforms, have aided this development (Helière et al. 2007, Peters et al. 2007). Synthetic aperture processing, used together with migration processing (inherited from seismic processing), reinstates energy to its true position in two- or three-dimensions, thereby increasing resolution. Secondly, the treatment of englacial attenuation, the loss of signal on its passage through the ice, has seen progress recently. Matsuoka (2011) highlighted the risks of over-interpreting bed returns in the absence of correct treatment of englacial attenuation, especially where the ice-flow regime and subglacial topography are complex (see Matsuoka et al. 2010 for a review). Thirdly, information in the bed returns other than, or supplementary to, the amplitude of the bed return is being used. For example, Murray et al. (2008) used coincident radar and seismic profiles to recover subglacial conditions, while Schroeder et al. (2013) used specular anisotropy of bed returns to image subresolution hydrological features largely independently of the effects of englacial attenuation.

Several researchers have sought to model flow routes beneath the ice sheet to develop the theory that water flows for great distances beneath the Antarctic ice sheet. Rémy \& Legrésy (2005) performed hydrological network analysis on high-resolution ice surface data over Wilkes Land, East Antarctica, mapping an inferred subglacial network that linked several known subglacial lakes. A significant assumption in their analysis was that surface topography on a broad-scale reflects the subglacial topography; though later work demonstrated that this only holds true under certain conditions (De Rydt et al. 2013). Siegert et al. (2007) modelled subglacial water routing across Antarctica using hydropotential methodology (Shreve 1972), which requires knowledge of the ice surface and the bed. Le Brocq et al. (2009) used a similar method when developing a 
subglacial water flow component for ice sheet modelling. The results of these exercises must be viewed with a confidence relative to our knowledge of bed topography and conditions across different regions, and in the context that small changes to the ice surface, such as external forcings or internal instabilities, can exert significant influences on subglacial water flowpaths (Wright et al. 2008). Carter et al. (2009b) modelled the probable flow mechanism and impact on ice mass budget of the Adventure Lakes drainage event (described by Wingham et al. 2006). The authors suggested that the water flow was probably distributed along a broad, shallow water system, perhaps through basal sediments, and that this flowpath delayed the arrival of water to downstream points by approximately 12 months. Carter \& Fricker (2012) modelled the subglacial water flows to the Siple Coast. The aforementioned studies have all assumed, or inferred, that most subglacial water flows through distributed drainage systems beneath the ice sheet. However, Le Brocq et al. (2013) observed supraglacial channels close to the grounding line on the surfaces of a number of ice shelves, and inferred that they may originate from concentrated outflows of subglacial water flowing along channelized flowpaths beneath the inland ice. Should this be true, and further data are required as confirmation, it challenges the way in which subglacial flows have been modelled. In support of this, Schroeder et al. (2013) demonstrated that, beneath Thwaites Glacier, the specularity of radar returns changed with respect to whether flightlines were parallel or perpendicular to ice flow, indicating the presence of distributed 'canals' and upward incising channels in the upstream and downstream parts of the bed, respectively.

Extensive surveys over parts of East Antarctica are proffering further insight into subglacial water routing. For example, Wright et al. (2012) presented a suite of evidence from an aerogeophysical survey over the $287000 \mathrm{~km}^{3}$ Aurora Basin to demonstrate that subglacial lakes near the Dome $\mathrm{C}$ ice divide probably discharge through Aurora Basin to the coast via Totten Glacier. A survey of the Gamburtsev Subglacial Mountains in East Antarctica has also provided a glimpse of the subglacial hydrological network in the deep interior (Wolovick et al. 2013). Water is predominantly routed along a system of alpine overdeepenings created during the early growth phase of the East Antarctic Ice Sheet, and the drainage networks follow valley floors either uphill or downhill depending on the gradient of the ice sheet surface. Where the water is forced uphill along the valley floor by the ice surface gradient, it terminates in or near distinct and sometimes very large (up to $25 \%$ of the ice column) plumes of refrozen basal ice which have strong potential to alter basal ice rheology and fabric, and are implicated in thickening the overlying ice column (Bell et al. 2011). These observations suggest that supercooling of basal water remains a significant, and perhaps underestimated, component of the subglacial water budget across Antarctica, by acting to recover water that would otherwise eventually drain to the margins.

Despite improved knowledge of the Antarctic subglacial hydrology, there remain few observations targeted towards monitoring changes in the subglacial hydrological system. The 'active' lake studies drew attention to the instability of subglacial water sources and flows (e.g. Gray et al. 2005, Wingham et al. 2006, Fricker et al. 2007), but the majority of evidence is provided indirectly by glaciodynamic instabilities that are probably associated with unstable water flows in the subglacial drainage system. A clear example of a glaciodynamic instability probably related to changes in subglacial water flow is provided by Kamb Ice Stream. Formerly fast-flowing like the other Siple Coast ice streams, it switched to a slow flow state more than a century ago (Retzlaff \& Bentley 1993). Anandakrishnan \& Alley (1997) surmised that the stagnation of flow resulted from piracy of much of the 'lubricating' subglacial water to neighbouring Whillans Ice Stream, allowing localized 'sticky spots' to gain eminence sufficient to deactivate fast flow. Catania et al. (2006) presented further evidence that around the same time the margin of Kamb Ice Stream shifted inwards, resulting in a narrowing of the ice stream trunk and discharge capacity by $c .30 \%$. Other authors have shown that with lower water fluxes much of the remaining water has been susceptible to basal freeze-on (Christoffersen \& Tulaczyk 2003, Vogel et al. 2005). Examination of sediments recovered from beneath Kamb Ice Stream (Engelhardt \& Kamb 2013), ancillary evidence from ice surface flow-lines extending across the ice shelf (Hulbe \& Fahnestock 2007) and modelling (Christoffersen et al. 2010, Catania et al. 2012, Van der Wel et al. 2013) suggest that over long timescales Kamb Ice Stream may undergo cycles of activity and stagnation; the cause of the initial piracy or recovery of water flows beneath the ice stream remains enigmatic. Evidence of ice stream stagnation probably due to water piracy has also been reported from Carlson Inlet/Rutford Ice Stream (Vaughan et al. 2008) and in the Ragnhild Glacier system of East Antarctica (Pattyn et al. 2005).

Seismic techniques have been successfully deployed to observe changes in the subglacial hydrological system beneath Antarctica. For example, repeat active-seismic surveys on Rutford Ice Stream have shown switches in hydrological behaviour at the same site surveyed at six/seven year intervals (Smith et al. 2007). In another study, Winberry et al. (2009) used passive seismic sensors to record a crack opening towards the bed and to 'hear' rushing water for a period of ten minutes at the bed of MacAyeal Ice Stream. These studies offer a tantalizing hint of the potential rapidity with which changes take place in the subglacial hydrological system beneath 
Antarctica, but improved knowledge requires more extensive deployment in terms of both spatial spread and repeat measurements.

\section{Grand challenges}

In the last decade, due to technological advances in remote sensing and exploratory geophysics, coupled with improved theoretical conceptions of subglacial processes beneath the major ice sheets, vast improvements have been made in our knowledge of the ways in which subglacial water is generated, stored, flows beneath and ultimately leaves the Antarctic ice sheet. Some of the grand challenges that now lie ahead are identified and discussed below.

\section{Technological improvements and the expansion of the observational base}

To date, technology has been key to observing subglacial hydrological phenomena, whether using geophysical techniques to image the basal environment (e.g. Blankenship et al. 1986, Woodward et al. 2010), improving drilling to access it (e.g. Siegert et al. 2011), or in developing new ways of interpreting subglacial hydrological behaviour from spaceborne remote sensing observations of the ice surface (e.g. Fricker et al. 2007). Regarding the latter, continued observations of ice surface change, such as by CryoSat (McMillan et al. 2013) and IceSAT/IceBridge programs (Fricker et al. 2010), offer efficient data capture, could be targeted over predicted subglacial lakes and water flowpaths (cf. Livingstone et al. 2013), and calibrated with field measurements over inferred lakes (e.g. Christianson et al. 2012, Siegert et al. 2014). At the same time, it is important not to neglect observational programmes on and over the ice that could pick up subglacial hydrological changes too subtle to be detected by spaceborne remote sensing, but which may still significantly impact on ice dynamics. Radar instrumentation and processing is one area in which advances have been particularly apparent over the last decade, driven in part by the NASA IceBridge program. Research into beam-forming processing techniques offers the exciting potential for a multi-antennae array to survey swaths of the ice bed, similar to bathymetric multi-beam sonar surveying, vastly improving the efficiency of radar surveys (Paden et al. 2010, Wu et al. 2011). The development and application of ultra-wide-band sensors (e.g. Laird et al. 2010) offer similar prospects for extracting basal properties at an increasing resolution. These advances will require an increased understanding of how radar signals interact with the ice bed interface, in particular with shallow lake environments (e.g. Gorman $\&$ Siegert 1999). One method to decrease this ambiguity is through the increased use of reflectivity modelling with both real and synthetic datasets (e.g. MacGregor et al. 2011). A significant challenge for radar surveying lies in improving the treatment of englacial attenuation (e.g. Matsuoka et al. 2010, Matsuoka 2011, Ashmore et al. 2014) and improving our ability to discriminate between water at the bed versus contrasts in subglacial geology. Undertaking radar surveys in tandem with seismic surveys (e.g. Murray et al. 2008) or potential-field surveying (e.g. Smith et al. 2013) offers promise for these objectives. Completing combined seismic and radar surveys over larger areas would be aided significantly by new seismic instrumentation. Truck-mounted sweptfrequency sources (Vibroseis), as are used in terrestrial hydrocarbon exploration, with snow streamer receivers (Hofstede et al. 2013), offer a more efficient method for seismic data collection in the future. While a programme of direct-access measurements of hydrology at the ice base would offer the most direct observations, it would be expensive and logistically challenging. Therefore, in the medium-term, our best hope of acquiring observations to improve understanding of subglacial hydrology remains with continuing geophysical survey programmes, especially the use of radar to identify hydrological variability.

\section{Improved understanding of the geothermal heat flux in Antarctica}

With supraglacial meltwater inputs to the subglacial system precluded in Antarctica, one of the root causes of subglacial hydrological variability is probably spatial and temporal variations in the generation of subglacial meltwater at the ice sheet base. Therefore, a key objective must be to obtain an improved understanding of a chief control on subglacial meltwater generation, namely the geothermal heat flux, thereby predicting the magnitude of subglacial melt from different regions beneath the ice sheet. Spatial maps of geothermal heat flux based on global seismic modelling (Shapiro \& Ritzwoller 2004) or satellite magnetic measurements (Maule et al. 2005) are currently being used, in part, to derive first-order estimates of subglacial melt (e.g. Pattyn 2010). However, without direct measurements to calibrate these maps, and considering that in some locations they differ enormously in their distributions, there remains considerable uncertainty over the magnitude of geothermal heat flux in many locations. Ultimately, an integrated multi-dataset-based geothermal heat flux model is required for Antarctica, similar to that produced for Greenland (cf. Rogozhina et al. 2012). Additional datasets that could be used to support such an objective include airborne- and satellite-acquired gravity data (e.g. Vaughan et al. 2003), as well as calibration from rapid-access drilling to the bed of the ice sheet in as many locations as possible, and the use of subglacial lakes and other radar-imaged 'wet' basal returns to calibrate locations of warm-based ice. 


\section{Improved understanding of subglacial water flowpaths and mechanisms}

While most modelling of subglacial water flowpaths in Antarctica has assumed that subglacial water follows distributed flowpaths, the findings of Le Brocq et al. (2013) suggest that channelized flowpaths can exist from some way inland of the grounding line. Hence, a challenge ahead is to discern what conditions are required to keep large subglacial channels open beneath ice streams, and understand the impact this may have on overlying ice dynamics. As part of engaging with this challenge, a requirement will be to understand how the subglacial drainage system may evolve beneath an ice stream in the absence of supraglacial forcing, which is known to be the chief forcing mechanism behind subglacial drainage system evolution in alpine and Arctic systems (cf. Nienow et al. 1998, Bartholomew et al. 2010). Subglacial lakes, in particular the regular or irregular drainage from upstream to downstream locations and ultimately to the ice margin, represent one mechanism for initiating the large subglacial water flows one might conceive are necessary for channelization, but how channels remain open underneath deep ice for periods exceeding the length of each drainage event is unknown. Repeat seismic surveys of Rutford Ice Stream have been informative on the changing subglacial environment (Smith et al. 2007) but remain time-consuming and below the temporal resolution of hydrological changes. Geophysical installations, as have been performed in Alpine environments (Kulessa et al. 2008), may provide information on subglacial hydrological dynamics at higher temporal resolution. Passive seismic and GPS installations, in particular, may be useful for elucidating the temporal aspect of subglacial drainage and the interaction of water with the substrate (e.g. Winberry et al. 2009, 2011).

\section{Determining the role of subglacial water in ice sheet mass balance}

The demonstrable dynamism in subglacial water beneath Antarctica throws into doubt the previously unstated assumption that the role of subglacial water in ice sheet mass balance is negligible. In interior regions, for example, local mass balance may be affected by the widespread phenomenon of substantial volumes of subglacial melt freezing back on to the underside of the ice at bedrock perturbations to form large blocks of accreted ice. This not only removes water that would otherwise have drained downstream, but also affects the internal flow properties of the ice (Bell et al. 2011). On the scale of an ice sheet, the amount of water that is lost to groundwater flow beneath the ice is unknown, and there is limited knowledge of typical volumes of water lost to outburst events at the margin. There is only one published observation of an active subglacial outburst from the
Antarctic ice sheet (Law Dome, East Antarctica; Goodwin 1988), and it is probable that most meltwater leaves the ice sheet unobserved across the grounding line and directly into the ocean. One aspect of subglacial water routing, not considered until now, was described by Uemera et al. (2011) who measured an upward freshwater groundwater flux offshore of East Antarctica, which may have been re-emerging subglacial meltwater. New and innovative ways are required to identify probable water outflows from the Antarctic ice sheet and their impact on the ice sheet mass balance.

\section{Uniting geomorphology and process-glaciology to consolidate understanding}

For many years, the labyrinthine landscape of subglacially-carved channels exposed in the Dry Valleys of East Antarctica, studied by David Sugden and colleagues (cf. Sugden \& John 1976 p. 1, Sugden et al. 2006), has presented clear evidence not only that subglacial water flows occur beneath the Antarctic ice sheet, but that they occur with sufficient magnitudes to scour their signal clearly across the subglacial surface, even where that surface consists of hard rock. Offshore from the present-day Antarctic coastline, across the continental shelf which lay under an expanded ice sheet during the Last Glacial Maximum, there is ample evidence of abundant channels and cavities carved into the subglacial surface by inferred subglacial drainage pathways (e.g. Nitsche et al. 2013). The existence of these signals across the landscape invites the question: how effective is subglacial drainage beneath the Antarctic ice sheet as an active erosional agent, and how effective is it at transporting material from the ice sheet interior to the margin? More generally, it serves as the latest refresher that there is much to be gained from continual knowledge transfer and exchange of ideas between the glacial geomorphology and process-glaciology communities.

\section{Acknowledgements}

DWA and RGB wish to thank the University of Aberdeen College of Physical Sciences, the Scottish Alliance for Geoscience, Environment and Society, and the Royal Astronomical Society for financial support towards the production of this paper. We also thank David Rippin, an anonymous reviewer, and the scientific editor Andrew Mackintosh for thorough reviews that benefitted the final manuscript.

\section{References}

Alley, R.B., Blankenship, D.D., Rooney, S.T. \& Bentley, C.R. 1989. Water-pressure coupling of sliding and bed deformation. 3. Application to ice stream B, Antarctica. Journal of Glaciology, 35, 130-139. 
Anandakrishnan, S. \& Alley, R.B. 1997. Stagnation of ice stream C, West Antarctica, by water piracy. Geophysical Research Letters, 24, 265-268.

Ashmore, D.W., Bingham, R.G., Hindmarsh, R.C.A., Corr, H.F.J. \& Joughin, I.R. 2014. The relationship between sticky spots and radar reflectivity beneath an active West Antarctic ice stream. Annals of Glaciology, 55, 29-38.

BAKer, V.R. \& Bunker, R.C. 1985. Cataclysmic Late Pleistocene flooding from Glacial Lake Missoula: a review. Quaternary Science Reviews, 4, 1-41.

Bamber, J.L., Gomez-Dans, J.L. \& Griggs, J.A. 2009. A new $1 \mathrm{~km}$ digital elevation model of the Antarctic derived from combined satellite radar and laser data. Part 1: Data and methods. Cryosphere, 3, 101-111.

Bartholomew, I., Nienow, P., Mair, D., Hubbard, A., King, M.A. \& Sole, A. 2010. Seasonal evolution of subglacial drainage and acceleration in a Greenland outlet glacier. Nature Geoscience, 3, 408-411.

Bell, R.E., Studinger, M., Shuman, C.A., Fahnestock, M.A. \& Joughin, I. 2007. Large subglacial lakes in East Antarctica at the onset of fast-flowing ice streams. Nature, 445, 904-907.

Bell, R.E., Studinger, M., Tikku, A.A., Clarke, G.K.C., Gutner, M.M. \& Meertens, C. 2002. Origin and fate of Lake Vostok water frozen to the base of the East Antarctic Ice Sheet. Nature, 416, 307-310.

Bell, R.E., Ferraccioli, F., Creyts, T.T., Braaten, D., Corr, H., Das, I., Damaske, D., Frearson, N., Jordan, T., Rose, K., Studinger, M. \& Wolovick, M. 2011. Widespread persistent thickening of the East Antarctic Ice Sheet by freezing from the base. Science, 331, 1592-1595.

Bentley, C.R., LoRd, N. \& Liu, C. 1998. Radar reflections reveal a wet bed beneath stagnant ice stream $\mathrm{C}$ and a frozen bed beneath ridge $\mathrm{BC}$, West Antarctica. Journal of Glaciology, 44, 149-156.

Bentley, M.J., Christoffersen, P., Hodgson, D.A., Smith, A.M., Tulaczyk, S. \& Le Broce, A.M. 2011. Subglacial lake sediments and sedimentary processes: potential archives of ice sheet evolution, past environmental change, and the presence of life. Geophysical Monograph, 192, 83-110.

Bingham, R.G., Hubbard, A.L., Nienow, P.W. \& Sharp, M.J. 2008. An investigation into the mechanisms controlling seasonal speedup events at a High Arctic glacier. Journal of Geophysical Research - Earth Surface, 113, 10.1029/2007JF000832.

Blankenship, D.D., Bentley, C.R., Rooney, S.T. \& Alley, R.B. 1986. Seismic measurements reveal a saturated porous layer beneath an active Antarctic ice stream. Nature, 322, 54-57.

Blankenship, D.D., Bell, R.E., Hodge, S.M., Brozena, J.M., Behrendt, J.C. \& FinN, C.A. 1993. Active volcanism beneath the West Antarctic Ice Sheet and implications for ice-sheet stability. Nature, 361, 526-529.

CARTER, S.P. \& FrickER, H.A. 2012. The supply of subglacial meltwater to the grounding line of the Siple Coast, West Antarctica. Annals of Glaciology, 53, 267-280.

Carter, S.P., Blankenship, D.D., Young, D.A. \& Holt, J.W. 2009a. Using radar-sounding to identify the distribution and sources of subglacial water: application to Dome C, East Antarctica. Journal of Glaciology, 55, 1025-1040.

Carter, S.P., Blankenship, D.D., Peters, M.E., Young, D.A., Holt, J.W. \& Morse, D.L. 2007. Radar-based subglacial lake classification in Antarctica. Geochemistry Geophysics Geosystems, 8 , 10.1029/2006GC001408.

Carter, S.P., Blankenship, D.D., Young, D.A., Peters, M.E., Holt, J.W. \& Siegert, M.J. 2009b. Dynamic distributed drainage implied by the flow evolution of the 1996-1998 Adventure Trench subglacial lake discharge. Earth and Planetary Science Letters, 283, 24-37.
Catania, G.A., Scambos, T.A., Conway, H. \& Raymond, C.F. 2006. Sequential stagnation of Kamb Ice Stream, West Antarctica. Geophysical Research Letters, 33, 10.1029/2006GL026430.

Catania, G.A., Conway, H.B., Gades, A.M., Raymond, C.F. \& EngelHard, H. 2003. Bed reflectivity beneath inactive ice streams in West Antarctica. Annals of Glaciology, 36, 287-291.

Catania, G., Hulbe, C., Conway, H., Scambos, T.A. \& Raymond, C.F. 2012. Variability in the mass flux of the Ross ice streams, West Antarctica, over the last millennium. Journal of Glaciology, 58, 741-752.

Christianson, K., Jacobel, R.W., Horgan, H.J., Anandakrishnan, S. \& AlLEY, R.B. 2012. Subglacial Lake Whillans: ice-penetrating radar and GPS observations of a shallow active reservoir beneath a West Antarctic ice stream. Earth and Planetary Science Letters, 331, 237-245.

Christoffersen, P. \& TulaczyK, S. 2003. Response of subglacial sediments to basal freeze-on - 1. Theory and comparison to observations from beneath the West Antarctic Ice Sheet. Journal of Geophysical Research - Solid Earth, 108, 10.1029/2002JB001935.

Christoffersen, P., Tulaczyk, S. \& Behar, A. 2010. Basal ice sequences in Antarctic ice stream: exposure of past hydrologic conditions and a principal mode of sediment transfer. Journal of Geophysical Research - Earth Surface, 115, 10.1029/2009JF001430.

Corr, H.F.J. \& Vaughan, D.G. 2008. A recent volcanic eruption beneath the West Antarctic Ice Sheet. Nature Geoscience, 1, 122-125.

Cuffey, K.M. \& Paterson, W.S.B. 2010. The physics of glaciers, 4th ed. Amsterdam: Elsevier, 704 pp.

Denton, G.H. \& Sugden, D.E. 2005. Meltwater features that suggest Miocene ice-sheet overriding of the Transantarctic Mountains in Victoria Land, Antarctica. Geografiska Annaler - Physical Geography, 87A, 67-85.

De Rydt, J., Gudmundsson, G.H., Corr, H.F.J. \& Christoffersen, P. 2013. Surface undulations of Antarctic ice streams tightly controlled by bedrock topography. Cryosphere, 7, 407-417.

Dowdeswell, J.A. \& Siegert, M.J. 2003. The physiography of modern Antarctic subglacial lakes. Global and Planetary Change, 35, 221-236.

Engelhardt, H. \& Kamb, B. 1997. Basal hydraulic system of a West Antarctic ice stream: constraints from borehole observations. Journal of Glaciology, 43, 207-230.

Engelhardt, H. \& Kamb, B. 2013. Kamb Ice Stream flow history and surge potential. Annals of Glaciology, 54, 287-298.

Engelhardt, H., Humphrey, N., Kamb, B. \& Fahnestock, M. 1990. Physical conditions at the base of a fast moving Antarctic ice stream. Science, 248, 57-59.

Evatt, G.W., Fowler, A.C., Clark, C.D. \& Hulton, N.R.J. 2006. Subglacial floods beneath ice sheets. Philosophical Transactions of the Royal Society, 364A, 1769-1794.

Fountain, A.G. \& WaLder, J.S. 1998. Water flow through temperate glaciers. Reviews of Geophysics, 36, 299-328.

Fricker, H.A. \& SCAmbos, T. 2009. Connected subglacial lake activity on lower Mercer and Whillans ice streams, West Antarctica, 2003-2008. Journal of Glaciology, 55, 303-315.

Fricker, H.A., Scambos, T., Bindschadler, R. \& Padman, L. 2007. An active subglacial water system in West Antarctica mapped from space. Science, 315, 1544-1548.

Fricker, H.A., Scambos, T., Carter, S., Davis, C., Haran, T. \& Joughin, I. 2010. Synthesizing multiple remote-sensing techniques for subglacial hydrologic mapping: application to a lake system beneath MacAyeal Ice Stream, West Antarctica. Journal of Glaciology, 56, 187-199.

Fricker, H.A., Powell, R. \& Priscu, J. \& 11 others. 2011. Siple Coast subglacial aquatic environments: the Whillans Ice Stream Subglacial Access Research Drilling Project. Geophysical Monograph, 192, 199-219.

Fujita, S., Holmlund, P., Matsuoka, K., Enomoto, H., Fukai, K., Nakazawa, F., Sugiyama, S. \& Surdyk, S. 2012. Radar diagnosis of the subglacial conditions in Dronning Maud Land, East Antarctica. Cryosphere, 6, 1203-1219. 
GADES, A.M. 1998. Spatial and temporal variations of basal conditions beneath glaciers and ice sheets inferred from radio echo sounding. $\mathrm{PhD}$ thesis, University of Washington, 192 pp. [Unpublished.]

Gades, A.M., Raymond, C.F., Conway, H. \& Jacobel, R.W. 2000. Bed properties of Siple Dome and adjacent ice streams, West Antarctica, inferred from radio-echo sounding measurements. Journal of Glaciology, 46, 88-94.

Glasser, N.F. \& Scambos, T.A. 2008. A structural glaciological analysis of the 2002 Larsen B ice-shelf collapse. Journal of Glaciology, 54, 3-16.

GoodwIN, I.D. 1988. The nature and origin of a jökulhlaup near Casey Station, Antarctica. Journal of Glaciology, 34, 95-101.

Gorman, M.R. \& Siegert, M.J. 1999. Penetration of Antarctic subglacial Lakes by VHF electromagnetic pulses: information on depth and electrical conductivity of basal water bodies. Journal of Geophysical Research - Solid Earth, 104, 29 311-29 320.

Gray, L., Joughin, I., Tulaczyk, S., Spikes, V.B., Bindschadler, R. \& JEZEK, K. 2005. Evidence for subglacial water transport in the West Antarctic Ice Sheet through three-dimensional satellite radar interferometry. Geophysical Research Letters, 32, 10.1029/ 2004 GL021387.

Helière, F., Lin, C.-C., Corr, H. \& Vaughan, D. 2007. Radio echo sounding of Pine Island Glacier, West Antarctica: aperture synthesis processing and analysis of feasibility from space. IEEE Transactions on Geoscience and Remote Sensing, 45, 2573-2582.

Hock, R. \& Hoокe, R.L. 1993. Evolution of the internal drainage system in the lower part of the ablation area of Storglaciären, Sweden. Geological Society of America Bulletin, 105, 537-546.

Hofstede, C., Eisen, O., Diez, A., Jansen, D., Kristoffersen, Y., LAMBrecht, A. \& MAYER, C. 2013. Investigating englacial reflections with vibro- and explosive-seismic surveys at Halvfarryggen ice dome, Antarctica. Annals of Glaciology, 54, 189-200.

Horgan, H.J., Anandakrishnan, S., Jacobel, R.W., Christianson, K., Alley, R.B., Heeszel, D.S., Picotti, S. \& Walter, J.I. 2012. Subglacial Lake Whillans: seismic observations of a shallow active reservoir beneath a West Antarctic ice stream. Earth and Planetary Science Letters, 331, 201-209.

Hubbard, B. \& Nienow, P. 1997. Alpine subglacial hydrology. Quaternary Science Reviews, 16, 939-955.

Hulbe, C.L. \& Fahnestock, M.L. 2007. Century-scale discharge, stagnation and reactivation of the Ross ice streams, West Antarctica. Journal of Geophysical Research - Earth Surface, 112, 10.1029/2006JF000603.

Hulbe, C.L., Scambos, T.A., Youngberg, T. \& Lamb, A.K. 2008. Patterns of glacier response to disintegration of the Larsen B ice shelf, Antarctic Peninsula. Global and Planetary Change, 63, 1-8.

Iken, A. \& Bindschadler, R.A. 1986. Combined measurements of subglacial water pressure and surface velocity of Findelengletscher, Switzerland: conclusions about drainage system and sliding mechanism. Journal of Glaciology, 32, 101-119.

Jacobel, R.W., Welch, B.C., Osterhouse, D., Pettersson, R. \& MACGregor, J.A. 2009. Spatial variation of radar-derived basal conditions on Kamb Ice Stream, West Antarctica. Annals of Glaciology, 50, 10-16.

Jacobel, R.W., Lapo, K.E., Stamp, J.R., Youngblood, B.W., Welch, B.C. \& BAMBER, J.L. 2010. A comparison of basal reflectivity and ice velocity in East Antarctica. Cryosphere, 4, 447-452.

КАмв, B. 1987. Glacier surge mechanism based on linked cavity configuration of the basal water conduit system. Journal of Geophysical Research - Solid Earth and Planets, 92, 9083-9100.

King, E.C., Hindmarsh, R.C.A. \& Stokes, C.R. 2009. Formation of mega-scale glacial lineations observed beneath a West Antarctic ice stream. Nature Geoscience, 2, 585-588.

King, E.C., Woodward, J. \& Smith, A.M. 2004. Seismic evidence for a water-filled canal in deforming till beneath Rutford Ice Stream, West Antarctica. Geophysical Research Letters, 31, 10.1029/2004GL020379.
Kulessa, B., Boоth, A.D., Hobbs, A. \& Hubbard, A.L. 2008. Automated monitoring of subglacial hydrological processes with ground-penetrating radar (GPR) at high temporal resolution: scope and potential pitfalls. Geophysical Research Letters, 35, 10.1029/2008GL035855.

Laird, C.M., Blake, W.A., Matsuoka, K., Conway, H., Allen, C.T., Leucschen, C.J. \& Gogineni, S. 2010. Deep ice stratigraphy and basal conditions in central West Antarctica revealed by coherent radar. IEEE Geoscience and Remote Sensing Letters, 7, 246-250.

Langley, K., Kohler, J., Matsuoka, K., Sinisalo, A., Scambos, T., Neumann, T., Muto, A., Winther, J.G. \& Albert, M. 2011. Recovery Lakes, East Antarctica: radar assessment of sub-glacial water extent. Geophysical Research Letters, 38, 10.1029/2010GL046094.

Le Brocq, A.M., Payne, A.J., Siegert, M.J. \& Alley, R.B. 2009. A subglacial water-flow model for West Antarctica. Journal of Glaciology, 55, 879-888.

Le Brocq, A.M., Ross, N., Griggs, J.A., Bingham, R.G., Corr, H.F.J., Ferraccioli, F., Jenkins, A., Jordan, T.A., Payne, A.J., Rippin, D.M. \& Siegert, M.J. 2013. Evidence from ice shelves for channelized meltwater flow beneath the Antarctic ice sheet. Nature Geoscience, 6 , 945-948.

Lewis, A.R., Marchant, D.R., Kowalewski, D.E., Baldwin, S.L. \& WebB, L.E. 2006. The age and origin of the Labyrinth, western Dry Valleys, Antarctica: evidence for extensive middle Miocene subglacial floods and water freshwater discharge into the Southern Ocean. Geology, 34, 513-516.

Livingstone, S.J., Clark, C.D., Woodward, J. \& Kingslake, J. 2013. Potential subglacial lake locations and meltwater drainage pathways beneath the Antarctic and Greenland ice sheets. Cryosphere, 7, $1721-1740$.

MacGregor, J.A., Anandakrishnan, S., Catania, G.A. \& WinebrenNer, D.P. 2011. The grounding zone of the Ross Ice Shelf, West Antarctica, from ice-penetrating radar. Journal of Glaciology, 57, 917-928.

MacGregor, J.A., Catania, G.A., Conway, H., Schroeder, D.M., Joughin, I., Young, D.A., KempF, S.D. \& Blankenship, D.D. 2013. Weak bed control of the eastern shear margin of Thwaites Glacier, West Antarctica. Journal of Glaciology, 59, 900-912.

McMillan, M., Corr, H., Shepherd, A., Ridout, A., Laxon, S. \& Cullen, R. 2013. Three-dimensional mapping by CryoSat-2 of subglacial lake volume changes. Geophysical Research Letters, 40, 4321-4327.

Mair, D., Nienow, P., Sharp, M.J., Wohlleben, T. \& Willis, I. 2002. Influence of subglacial drainage system evolution on glacier surface motion: Haut Glacier d'Arolla, Switzerland. Journal of Geophysical Research - Solid Earth, 107, 10.1029/2001JB000514.

Marchant, D.R., Jamieson, S.S.R. \& Sugden, D.E. 2011. The geomorphic signature of massive subglacial floods in Victoria Land, Antarctica. Geophysical Monograph, 192, 111-126.

Margerison, H.R., Phillips, W.M., Stuart, F.M. \& Sugden, D.E. 2005. Cosmogenic ${ }^{3} \mathrm{He}$ concentrations in ancient flood deposits from the Coombs Hills, northern Dry Valleys, East Antarctica: interpreting exposure ages and erosion rates. Earth and Planetary Science Letters, 230, 163-175.

Matsuoka, K. 2011. Pitfalls in radar diagnosis of ice-sheet bed conditions: lessons from englacial attenuation models. Geophysical Research Letters, 38, 10.1029/2010GL046205.

Matsuoka, K., MacGregor, J.A. \& Pattyn, F. 2010. Using englacial radar attenuation to better diagnose the subglacial environment: a review. 13th International Conference on Ground Penetrating Radar (GPR), 19-23 June, 2010. GPR Proceedings 2010, 10.1109/ ICGPR.2010.5550161.

Matsuoka, K., Pattyn, F., Callens, D. \& Conway, H. 2012. Radar characterization of the basal interface across the grounding zone of an ice-rise promontory in East Antarctica. Annals of Glaciology, 53, $29-34$. 
Matsuoka, K., Gades, A., Conway, H., Catania, G. \& Raymond, C.F. 2009. Radar signatures beneath a surface topographic lineation near the outlet of Kamb Ice Stream and Engelhardt Ice Ridge, West Antarctica. Annals of Glaciology, 50, 98-104.

Maule, C.F., Purucker, M.E., Olsen, N. \& Mosegaard, K. 2005. Heat flux anomalies in Antarctica revealed by satellite magnetic data. Science, 309, 464- 467.

Müller, F. \& Iken, A. 1973. Velocity fluctuations and water regime of arctic valley glaciers. International Association of Scientific Hydrology Publications, 95, 165-182.

Murray, T., Corr, H., Forieri, A. \& Smith, A.M. 2008. Contrasts in hydrology between regions of basal deformation and sliding beneath Rutford Ice Stream, West Antarctica, mapped using radar and seismic data. Geophysical Research Letters, 35, 10.1029/ 2008GL033681.

Nienow, P., Sharp, M. \& Willis, I. 1998. Seasonal changes in the morphology of the subglacial drainage system, Haut Glacier d'Arolla, Switzerland. Earth Surface Processes and Landforms, 23, 825-843.

Nitsche, F.O., Gohl, K., Larter, R.D., Hillenbrand, C.D., Kuhn, G., Smith, J.A., Jacobs, S., Anderson, J.B. \& Jakobsson, M. 2013. Paleo ice flow and subglacial meltwater dynamics in Pine Island Bay, West Antarctica. Cryosphere, 7, 249-262.

Paden, J., Akins, T., Dunson, D., Allen, C. \& Gogineni, P. 2010. Ice-sheet bed 3-D tomography. Journal of Glaciology, 56, 3-11.

PatTyn, F. 2010. Antarctic subglacial conditions inferred from a hybrid ice sheet/ice stream model. Earth and Planetary Science Letters, 295, 451-461.

PatTyn, F. 2011. Antarctic subglacial lake discharges. Geophysical Monograph, 192, 27-44.

Pattyn, F., De Brabander, S. \& Huyghe, A. 2005. Basal and thermal control of the Ragnhild glaciers, East Antarctica. Annals of Glaciology, 40, 225-231.

Pattyn, F., De Smedt, B. \& Souchez, R. 2004. Influence of subglacial Vostok Lake on the regional ice dynamics of the Antarctic ice sheet: a model study. Journal of Glaciology, 50, 583-589.

Payne, A.J., Holland, P.R., ShePherd, A.P., Rutt, I.C., Jenkins, A. \& Joughin, I. 2007. Numerical modelling of ocean-ice interactions under Pine Island Bay's ice shelf. Journal of Geophysical Research Oceans, 112, 10.1029/2006JC003733.

Peters, L.E., Anandakrishnan, S., Alley, R.B. \& Smith, A.M. 2007. Extensive storage of basal meltwater in the onset region of a major West Antarctic ice stream. Geology, 35, 251-254.

Peters, M.E., Blankenship, D.D. \& Morse, D.L. 2005. Analysis techniques for coherent airborne radar sounding: application to West Antarctic ice streams. Journal of Geophysical Research - Solid Earth, 110, 10.1029/2004JB003222.

Peters, M.E., Blankenship, D.D., Carter, S.P., Kempf, S.D., Young, D.A. \& HolT, J.W. 2007. Along-track focusing of airborne radar sounding data from West Antarctica for improving basal reflection analysis and layer detection. IEEE Transactions on Geoscience and Remote Sensing, 45, 2725-2736.

Price, S.F., Payne, A.J., Catania, G.A. \& Neumann, T.A. 2008. Seasonal acceleration of inland ice via longitudinal coupling to marginal ice. Journal of Glaciology, 54, 213-219.

Priscu, J.C., Adams, E.E., Lyons, W.B., Voytek, M.A., Mogk, D.W., Brown, R.L., McKay, C.P., TaKaCs, C.D., Welch, K.A., Wolf, C.F., Kirshtein, J.D. \& Avci, R. 1999. Geomicrobiology of subglacial ice above Lake Vostok, Antarctica. Science, 286, 2141-2144.

Pritchard, H.D., Arthern, R.J., Vaughan, D.G. \& Edwards, L.A. 2009. Extensive dynamic thinning on the margins of the Greenland and Antarctic ice sheets. Nature, 461, 971-975.

Raymond, C.F., Catania, G.A., Nereson, N. \& van der Veen, C.F. 2006. Bed radar reflectivity across the north margin of Whillans Ice Stream, West Antarctica, and implications for margin processes. Journal of Glaciology, 52, 3-10.
Rémy, F. \& Legrésy, B. 2005. Subglacial hydrological networks in Antarctica and their impact on ice flow. Annals of Glaciology, 39, 67-72.

Retzlaff, R. \& Bentley, C.R. 1993. Timing of stagnation of Ice Stream C, West Antarctica, from short-pulse radar studies of buried surface crevasses. Journal of Glaciology, 39, 553-561.

Ridley, J.K., CudliP, W. \& LAXON, S.W. 1993. Identification of subglacial lakes using ERS-1 radar altimeter. Journal of Glaciology, 39, 625-634.

Rignot, E., Mouginot, J. \& Scheuchl, B. 2011. Ice flow of the Antarctic ice sheet. Science, 333, 1427-1430.

Rippin, D.M., Bamber, J.L., Siegert, M.J., Vaughan, D.G. \& CorR, H.F.J. 2003. Basal topography and ice flow in the Bailey/ Slessor region of East Antarctica. Journal of Geophysical Research Earth Surface, 108, 10.1029/2003JF000039.

Rippin, D.M., Bamber, J.L., Siegert, M.J., Vaughan, D.G. \& Corr, H.F.J. 2004. The role of ice thickness and bed properties on the dynamics of the enhanced-flow tributaries of Bailey Ice Stream and Slessor Glacier, East Antarctica. Annals of Glaciology, 39, 366-372.

Robin, G.D.Q., Drewry, D.J. \& Meldrum, D.T. 1977. International studies of ice sheet and bedrock. Philosophical Transactions of the Royal Society, 279B, 185-196.

Rogozhina, I., Hagedoom, J.M., Martinec, Z., Fleming, K., Soucek, O., Greve, R. \& Thomas, M. 2012. Effects of uncertainties in the geothermal heat flux distribution on the Greenland ice sheet: an assessment of existing heat flow models. Journal of Geophysical Research - Earth Surface, 117, 10.1029/2011JF002098.

Schroeder, D.M., Blankenship, D.D. \& Young, D.A. 2013. Evidence for a water system transition beneath Thwaites Glacier, West Antarctica. Proceedings of the National Academy of Sciences of the United States of America, 110, 12 225-12 228.

Shabtaie, S., Whillans, I.M. \& Bentley, C.R. 1987. The morphology of Ice Streams A, B, and C, West Antarctica, and their environs. Journal of Geophysical Research - Solid Earth and Planets, 92, 8865-8883.

Shannon, S.R., Payne, A.J. \& Bartholomew, I.D. \& 16 others. 2013. Enhanced basal lubrication and the contribution of the Greenland ice sheet to future sea-level rise. Proceedings of the National Academy of Sciences of the United States of America, 110, 14 156-14 161.

Shapiro, N.M. \& Ritzwoller, M.H. 2004. Inferring surface heat flux distributions guided by a global seismic model: particular application to Antarctica. Earth and Planetary Science Letters, 223, 213-224.

Shreve, R.L. 1972. Movement of water in glaciers. Journal of Glaciology, 11, 205-214.

Shtarkman, Y.M., Kocer, Z.A., Edgar, R., Veerapaneni, R.S., D'elia, T., Morris, P.F. \& Rogers, S.O. 2013. Subglacial Lake Vostok (Antarctica) accretion ice contains a diverse set of sequences from aquatic, marine and sediment-inhabiting bacteria and eukarya. PLOS ONE, 8, 10.1371/journal.pone.0067221.

Siegert, M.J. \& Bamber, J.L. 2000. Subglacial water at the heads of Antarctic ice stream tributaries. Journal of Glaciology, 46, 702-703.

Siegert, M.J., Kennicutt II, M.C. \& Bindschadler, R.A., eds. 2011. Antarctic subglacial aquatic environments. Washington, DC: American Geophysical Union, 246 pp.

Siegert, M.J., Le Broce, A. \& Payne, A.J. 2007. Hydrological connections between Antarctic subglacial lakes, the flow of water beneath the East Antarctic Ice Sheet and implications for sedimentary processes. In Hambrey, M.J., Christoffersen, P., Glasser, N.F. \& HubBard, B., eds. Glacial sedimentary processes and products. Special Publications of the International Association of Sedimentologists, No. 39, 3-10.

Siegert, M.J., Kwok, R., Mayer, C. \& Hubbard, B. 2000. Water exchange between the subglacial Lake Vostok and the overlying ice sheet. Nature, 403, 643-646.

Siegert, M.J., Ross, N., Corr, H., Smith, B., Jordan, T., Bingham, R.G., Ferraccioli, F., RipPin, D. \& Le BrocQ, A. 2014. Boundary conditions of an active West Antarctic subglacial lake: implications for storage of water beneath the ice sheet. Cryosphere, 8, 15-24. 
Skidmore, M. 2011. Microbial communities in Antarctic subglacial lake aquatic environments. Geophysical Monograph, 192, 61-81.

Smith, A.M. 1997a. Basal conditions on Rutford Ice Stream, West Antarctica, from seismic observations. Journal of Geophysical Research - Solid Earth, 102, 543-552.

SMITH, A.M. 1997b. Variations in basal conditions on Rutford Ice Stream, West Antarctica. Journal of Glaciology, 43, 245-255.

Smith, A.M., Jordan, T.A., Ferraccioli, F. \& Bingham, R.G. 2013. Influence of subglacial conditions on ice stream dynamics: seismic and potential field data from Pine Island Glacier, West Antarctica. Journal of Geophysical Research - Solid Earth, 118, 1471-1482.

Smith, A.M., Murray, T., Nicholls, K.W., Makinson, K., Adalgeirsdóttir, G., Behar, A.E. \& Vaughan, D.G. 2007. Rapid erosion, drumlin formation, and changing hydrology beneath an Antarctic ice stream. Geology, 35, 127-130.

Smith, B.E., Fricker, H.A., Joughin, I.R. \& TulaczyK, S. 2009. An inventory of active subglacial lakes in Antarctica detected by ICESat (2003-2008). Journal of Glaciology, 55, 573-595.

Sitees, V.B., Csatho, B.M., Hamilton, G.S. \& Whillans, I.M. 2003. Thickness changes on Whillans Ice Stream and Ice Stream C, West Antarctica, derived from laser altimeter measurements. Journal of Glaciology, 49, 223-230.

Statham, P.J., Skidmore, M. \& Tranter, M. 2008. Inputs of glacially derived dissolved and colloidal iron to the coastal ocean and implications for primary productivity. Global Biogeochemical Cycles, 22, 10.1029/2007GB003106.

Stearns, L.A., Smith, B.E. \& Hamilton, G.S. 2008. Increased flow speed on a large East Antarctic outlet glacier caused by subglacial floods. Nature Geoscience, 1, 827-831.

Studinger, M., Bell, R.E. \& TikKu, A.A. 2004. Estimating the depth and shape of subglacial Lake Vostok's water cavity from aerogravity data. Geophysical Research Letters, 31, 10.1029/2004GL019801.

Sugden, D. \& Denton, G. 2004. Cenozoic landscape evolution of the Convoy Range to Mackay Glacier area, Transantarctic Mountains: onshore to offshore synthesis. Geological Society of America Bulletin, 116, 840-857.

Sugden, D.E. \& John, B.S. 1976. Glaciers and landscape. London: Arnold, 376 pp.

Sugden, D.E., Bentley, M.J. \& Ó Cofaigh, C. 2006. Geological and geomorphological insights into Antarctic ice sheet evolution. Philosophical Transactions of the Royal Society, 364A, 1607-1625.

Sugden, D.E., Denton, G.H. \& Marchant, D.R. 1991. Subglacial meltwater channel systems and ice sheet overriding, Asgard Range, Antarctica. Geografiska Annaler - Physical Geography, 73A, 109-121.

Sundal, A.V., Shepherd, A., Nienow, P., Hanna, E., Palmer, S. \& Huybrechts, P. 2011. Melt-induced speed-up of Greenland ice sheet offset by efficient subglacial drainage. Nature, 469, 521-524.

Tedstone, A.J., Nienow, P.W., Sole, A.J., Mair, D.W.F., Cowton, T.R., Bartholomew, I.D. \& King, M.A. 2013. Greenland ice sheet motion insensitive to exceptional meltwater forcing. Proceedings of the National Academy of Sciences of America, 110, 19 719-19724.

Uemura, T., Taniguchi, M. \& Shibuya, K. 2011. Submarine groundwater discharge in Lützow-Holm Bay, Antarctica. Geophysical Research Letters, 38, 10.1029/2010GL046394.

Van de Wal, R.S.W., Boot, W., van Den Broeke, M.R., Smeets, C.J.P.P., ReIJMer, C.H., Donker, J.J.A. \& Oerlemans, J. 2008. Large and rapid melt-induced velocity changes in the ablation zone of the Greenland ice sheet. Science, 321, 111-113.

Van der Wel, N., Christofferson, P. \& Bougamont, M. 2013. The influence of subglacial hydrology on the flow of Kamb Ice Stream, West Antarctica. Journal of Geophysical Research - Earth Surface, 118, 97-110.

Van Liefferinge, B. \& Pattyn, F. 2013. Using ice-flow models to evaluate potential sites of million year-old ice in Antarctica. Climate of the Past, 9, 2335-2345.
Vaughan, D.G., Smith, A.M., Nath, P.C. \& Le Meur, E. 2003. Acoustic impedance and basal shear stress beneath four Antarctic ice streams. Annals of Glaciology, 36, 225-232.

Vaughan, D.G., Corr, H.F.J., Smith, A.M., Pritchard, H.D. \& SHEPHERD, A. 2008. Flow-switching and water piracy between Rutford Ice Stream and Carlson Inlet, West Antarctica. Journal of Glaciology, 54, 41-48.

Vogel, S.W. \& TulaczyK, S. 2006. Ice-dynamical constraints on the existence and impact of subglacial volcanism on West Antarctic Ice Sheet stability. Geophysical Research Letters, 33, 10.1029/ 2006GL027345.

Vogel, S.W., Tulaczyk, S., Kamb, B., Englehardt, H., Carsey, F.D., Behar, A.E., Lane, A.L. \& Joughin, I. 2005. Subglacial conditions during and after stoppage of an Antarctic ice stream: is reactivation imminent? Geophysical Research Letters, 32, 10.1029/2005GL022563.

WeERTMAn, J. 1957. On the sliding of glaciers. Journal of Glaciology, 3, $33-38$.

Winberry, J.P., Anandakrishnan, S. \& Alley, R.B. 2009. Seismic observations of transient subglacial water flow beneath MacAyeal Ice Stream, West Antarctica. Geophysical Research Letters, 36, 10.1029/ 2009GL037730.

Winberry, J.P., Anandakrishnan, S., Wiens, D.A., Alley, R.B. \& Christianson, K. 2011. Dynamics of stick-slip motion, Whillans Ice Stream, Antarctica. Earth and Planetary Science Letters, 305, 283-289.

Wingham, D.J., Siegert, M.J., Shepherd, A. \& Muir, A.S. 2006. Rapid discharge connects Antarctic subglacial lakes. Nature, 440, 1033-1036.

Wolovick, M.J., Bell, R.E., Creyts, T.T. \& Frearson, N. 2013. Identification and control of subglacial water networks under Dome A, Antarctica. Journal of Geophysical Research - Earth Surface, 118, $140-154$.

Woodward, J., Smith, A.M., Ross, N., Thoma, M., Corr, H.F.J., King, E.C., King, M.A., Grosfeld, K., Tranter, M. \& Siegert, M.J. 2010. Location for direct access to subglacial Lake Ellsworth: an assessment of geophysical data and modelling. Geophysical Research Letters, 37, 10.1029/2010GL042884.

Wright, A. \& Siegert, M. 2012. A fourth inventory of Antarctic subglacial lakes. Antarctic Science, 24, 659-664.

Wright, A.P., Siegert, M.J., Le BrocQ, A.M. \& Gore, D.B. 2008. High sensitivity of subglacial hydrological pathways in Antarctica to small ice-sheet changes. Geophysical Research Letters, 35, 10.1029/ 2008 GL034937.

Wright, A.P., Young, D.A., Roberts, J.L., Schroeder, D.M., Bamber, J.L., Dowdeswell, J.A., Young, N.W., Le Broce, A.M., Warner, R.C., Payne, A.J., Blankenship, D.D., van Ommen, T.D. \& SIEGERT, M.J. 2012. Evidence of a hydrological connection between the ice divide and ice sheet margin in the Aurora Subglacial Basin, East Antarctica. Journal of Geophysical Research - Earth Surface, 117, 10.1029/2011JF002066.

Wu, X.Q., Jezek, K.C., Rodriguez, E., Gogineni, S., RodriguezMorales, F. \& Freeman, A. 2011. Ice sheet bed mapping with airborne SAR tomography. IEEE Transactions on Geoscience and Remote Sensing, 49, 3791-3803.

Zirizzotti, A., Cafarella, L. \& Urbini, S. 2012. Ice and bedrock characteristics underneath Dome C (Antarctica) from radio echo sounding data analysis. IEEE Transactions on Geoscience and Remote Sensing, 50, 37-43.

Zirizzotti, A., Cafarella, L., Baskaradas, J.A., Tabacco, I.E., Urbini, S., Mangialetti, M. \& Bianchi, C. 2010. Dry-wet bedrock detection by radio echo sounding measurements. IEEE Transactions on Geoscience and Remote Sensing, 48, 2343-2348.

Zwally, H.J, Abdalati, W., Herring, T., Larson, K., Saba, J. \& STEFFEN, K. 2002. Surface-melt-induced acceleration of Greenland ice-sheet flow. Science, 297, 218-222. 